Vol. 2, No. 04; 2019

ISSN: 2581-4664

\title{
STAFF TRAINING AND DEVELOPMENT,ITS IMPACTS ON EMPLOYEES PERFORMANCE AND ORGANIZATIONAL PRODUCIVITY IN NIGERIA. A STUDY OF AKWA IBOM STATE MINISTRY OF FINANCE (2000-2018)
}

\author{
Ebong, Itoro Bassey \\ Department Of Political Science University Of Nigeria, Nsuka Enugu State \\ Nte, Eyo Bassey \\ Department Of Political Science \& Public Administration, University Of Uyo, Uyo, Akwa Ibom State \\ Obot, Mfon Asuquo \\ Department Of Political Science \&public Administration, University Of Uyo, Uyo, Akwa Ibom State
}

http://doi.org/10.35409/IJBMER.2019.2413

\begin{abstract}
The paper examined the impacts of staff training and development on the organizational performance and productivity using Akwa Ibom State Ministry of Finance as a focus point. This paper maintained that in spite of some outstanding efforts by government through various interventions and programmes directed towards effective staff training in Nigeria, the Nigerian public sector's score-card (especially the Nigerian Civil Service), has remained poor and inefficient due to shortage of skilled manpower, lack of adequate fund and facilities needed for effective staff training and development. The study adopted Historical and Descriptive research methods and data were collected using secondary sources. The population of the study was drawn from Akwa Ibom State Ministry of Finance. The major findings of the study revealed among others that: poor staff training and development lead to poor organizational productivity. The study also revealed that for any organization to grow and attained its objectives and goals, staffs training and development should be viewed with serious attention. This is because untrained employee's in organization tends to debilitate employee's performance which in turned affect organization productivities negatively. Based on the major findings, the paper recommended among others that Seminars, workshops, and regular conferences etc. should be organized promptly for all staffs of Akwa Ibom Ministry of Finance in order to equip them with modern techniques, skills towards actualizing the present and future needs of the organization. The paper also recommended that method and manners of selecting staffs for training and development should not be based on nepotism, favouratism as well as clientelism, but rather based on merit. This implies that those qualified and due for training should be given ultimate consideration and opportunity to do so if the organization wish to attained their set goals and objectives
\end{abstract}

Keyword: Staff Training and Development, Employee's Performance, Organizational Productivity.

\section{INTRODUCTION}

The history of staff training in business organizations is as long as the entire history of business organizations (Miller, 1996). This is because the knowledge base or skills of the normal 


\section{International Journal of Business Management and Economic Review}

Vol. 2, No. 04; 2019

ISSN: 2581-4664

employees in the labour market is not sufficient for the specialized tasks within the organizations. However, the academic study of various forms of training did not start until about a century ago, when researchers started a branch of research under the name of "vocational training" (Salas and Cannon Bowers, 2001). The beginning of the twentieth century and especially after World War II saw the widespread of training programs among organizations, involving more and more employees and also expanding in content (Luo, 2000). In the 1910s, only a few large companies such as Westinghouse, General Electric, and International Harvester had factory schools that focused on training technical skills for entry level workers. By the end of 1990, forty percent of the Fortune 500 firms in America had a corporate university or learning center (Meister, 1997).

Staff training in Nigeria could be traced back to 1960 when it was discovered that most of the top government and business positions were occupied by expatriates (Olalere and Adesoji, 2013). The departure of the whites after independence gave rise to a big vacuum of capable indigenous human capital. This prompted the Federal Government of Nigeria to set up a Manpower Board in 1962 following the Ashby Commissions Recommendations (Olalere and Adesoji, 2013). Consequently, the Federal Government of Nigeria established complimentary institutions like the Centre for Management Development (CMD), Administrative Staff College of Nigeria, Industrial Training Fund (ITF), and Federal Training Centre to train and retrain employees as well as give orientation to fresh graduates of formal academic institutions (Olalere and Adesoji, 2013).

Today, we are witnessing an overwhelming number of research studies from both descriptive and prescriptive traditions, focusing on several characteristics of training programs as well as their costs and benefits for business organizations (Becker and Gerhart, 1996). At the same time, organizations have come to better understand the significance of training for their survival in knowledge-intensive and volatile markets of this era, and thus have increasingly acknowledged the profitability of developing their human resources through various forms of training (Berge, 2001; Salas and Cannon-Bowers, 2001).

Training is a crucial area of human resource management; it is the fastest growing segment of personnel activities. Training which is referred to as a course and exercise for developing the employees' effective, cognitive and psychomotor skills assist the organizations to have a crucial method of developing the employee towards enhancing his productivity (Ezeani \& Oladele, 2013). Manpower training and development is one of the most important organizational dynamics. It constitutes the pivot in which organizational survival is run. The training process is one of the most pervasive methods for enhancing the productivity of individuals and communicating organizational goals to personnel. Manpower is the basis of all resources and it is the indispensable means of converting other resources to man kind's use and benefits. Manpower is the pivot of every human institution. Even in the developed and industrial nations of the world where the use of machines and technology is at an advanced stage, manpower is still very essential. Training therefore holds the key to unlock the potential growth and development opportunities to achieve a competitive edge. In this context, organizations train and develop their employees to the fullest advantage in order to enhance their effectiveness (Iftikhar and Siraj-ud-din, 2009) .

Training both physically, socially, intellectually and mentally are very essential in facilitating not only the level of productivity but also the development of personnel in any 


\section{International Journal of Business Management and Economic Review}

Vol. 2, No. 04; 2019

ISSN: 2581-4664

organization (Cole, 2002). To manage an organization both large and small requires staffing them with competent personnel. The formal educational system does not adequately teach specific job skills for a position in a particular organization. Few employees have the requisite skills, knowledge, abilities and competencies (SKAC) needed to work. As a result, many require extensive training to acquire the necessary SKAC to be able to make substantive contribution towards the organization's growth. In order to sustain economic growth and effective performance, it is important to optimize the contribution of employees to the aims and goals of the organizations.

In a developing country like Nigeria, training and development of manpower resources is highly needed in virtually all business organizations for its effectiveness (Armstrong, 2009). Deficiencies in knowledge, skills, and ability among public personnel, particularly those of Asia, Africa, and Latin America, are remarkable. Training is necessary to ensure an adequate supply of staff that is technically and socially competent and capable of career development into specialist departments or management positions. Therefore a continual need for the process of staff development, and training fulfill an important part of this process. Training should be viewed therefore as an integral part of the process of total quality management.

George \& Scott (2012), argues that the recognition of the importance of training in recent years has been heavily influenced by the intensification of competition and the relative success of organizations where investment in employee development is considerably emphasized. Training has the distinct role in the achievement of an organizational goal by incorporating the interests of organization and the workforce (Stone, 2002). The employee performance depends on various factors. But the most important factor of employee performance is training. Training is important to enhance the capabilities of employees. The employees who have more on the job experience have better performance because there is an increase in the both skills and competencies because of more on the job experience (Fakhar and Khan, 2008).

Despite the obvious significance of training, the enormous expansion in the content of training programs over time has largely been taken for granted. Often times, there are ulterior motives why employees are sent on training. Berge (2001) found out that some of those organizations that neglect employee training do so because of the huge cost of training and the fear of losing those employees after training them. To show the importance attached to staff training, Akwa Ibom State Ministry of Finance, conducts training on-the-job and off-the-job training for employees from time to time. To this end, the paper seeks to evaluate the impact of staff training and development on organization performance in an organization using Ministry of finance as a case study.

\section{STATEMENT OF THE PROBLEM}

One of the difficult challenges confronting management of most organizations today is how to make their workers become efficient and competence. This issue has led most organization to employ strategies by which to motivate their work force. Training is an effort initiated by organization to foster learning among its workers. Training and development are a continuous effort designed to improve employee's competence and performance (George\& Scott, 2012).

All organizations has predetermined objectives and goals, these objective or goals are the end toward which the activities of the organization are directed. Every organization strives to 


\section{International Journal of Business Management and Economic Review}

Vol. 2, No. 04; 2019

ISSN: 2581-4664

achieve their respective goals and objectives since this is the parameter for assessing their success or failure, and those objectives cannot be accomplished without human effort. Udoji in the service review commission has in his report stated that "of all the aspects of personnel management, perhaps the most important for Nigeria is training'. Training is virtually important in any organization setup be it private or public.

In spite of some outstanding efforts by government through various interventions and programmes towards effective staff training in Nigeria, the Nigerian public sector's score-card (especially the Nigerian Civil Service), has remained poor and inefficient due to shortage of skilled manpower, lack of adequate fund and facilities needed for effective staff training and development. Most Civil Service training centre and institution do not have modern training facilities such as computer, laboratories, libraries, and vehicles etc. to facilitate her staff training programme for effective service delivery. These in turn affect proper staff training process leading to staff inefficiency in service delivery. Misappropriation of funds assigned for effective staff development and training by the government also pose a great challenge over staff training and development. The effect of the above problems leads to ineffectiveness and inefficiency as well as poor quality and quantity of service delivery in both private and government Parastatal. Thus, the study focuses on the impact of staff training and organizational performance in government organization using Akwa Ibom State Ministry of finance as a focal point.

\section{CONCEPTUAL CLARIFICATIONS}

\section{Staff Training}

According to Nadler (1984), staff training is defined as a learning that is provided in order to improve performance on the present job. Staff training is a systematic process of altering the behaviour, knowledge or motivation of employees in a direction to increase the trainees' effectiveness and organization goal achievement.

For John (2001) staff training implies a set of activities that provides the opportunity to acquire job related skills. He observed that for organization to meet technological changes, it must train and retain employees to keep abreast of change in technology and be productive in their jobs. He also emphasized the role of staff training in management activity, especially the area of human resources management. According to him, the staff training function is a management activity in which the personnel department provides the necessary specialist knowledge and usually carried out, in addition to the administrative requirements that function which operates effectively with the organization.

Staff training can be carried out in many methods. Beardwell and Holden (1997) categorize training into two primary areas. On the job training; He also groups staff training into four areas; on the job training; off training, vestibule staff training and institutional training. Staff training must be a continuous activity in every organization, and needs to be given priority when the going gets tough because it is human resources of the organization that will take the actions necessary to turn the enterprise sound (Robert et al 1993).

Mullins (1996) opines that the purpose of staff training is to improve knowledge and skills and to change attitudes. He stresses that staff training can perform the following:

a. Increase the confidence, motivation and commitment of staff 


\section{International Journal of Business Management and Economic Review}

Vol. 2, No. 04; 2019

ISSN: 2581-4664
b. Give a feeling of personal satisfaction and achievement and broaden opportunities for career progression
c. Helps to improve the availability and quality of labour

\section{STAFF DEVELOPMENT}

There is a clear difference between staff training and development. Though both concepts geared towards increasing or improving the skills of workers in organization be it public or private. Training is concerned with teaching the workers specific skills, that will assist them in their immediate task. Development on the other hand, is concerned with teaching the workers more general skills that will assist them in career growth, thereby equipping them for future.

Cole, (1993). Defines Staff development as any activities which is directed towards future needs rather than present needs and which is concerned more with career growth than immediate performance. The intent of staff development programmes is to improve an employee's conceptual and human skills in preparation for future job. Flippo (1966), sees staff development as an act of increasing the knowledge and skill of an employee so that he can do a job as required. Staff development really enhances employee's productivity towards achieving organizational goals. According to him, effective staff development helps the employees to master more skills toward achieving organizational objectives.

Brown (1996) asserts staff development as the process of applying appropriate educational methodology to those situations in which improved performance can result from effective learning. Staff development primarily focuses teaching organizational members how to perform their current and future jobs and helping them require the knowledge and skills needed to be effective performers. To him, staff development is seen as the continuous, systematic development among all levels of employees welfare and that knowledge and those skills and attitudes which contribute to their welfare and that of the company.

Abiodun (1999), defines staff development as a systematic development of knowledge, skills and attitudes required by employees to perform adequately on a future task or job. The objective of staff development is to enable an employee to perform his job in such a way as to meet the standards of output, quality, safety and other operational requirements.

Hill (2000), opine that organizations embark on staff training and development programmes for many reasons, however these can be summarized as:

I. Productivity: People are employed for the simple reason of helping the organization to achieve its goals and this can only be done when the work is quite productive. Most staff training development programmes are therefore organized to help in increasing his productivity.

II. Effective: By increasing the workers skills he becomes effective in executing the task assigned to him.

III. Preparation for Higher Responsibilities: Though staff training programmes are targeted at improving the worker capacity to perform on his present duty, it equally helps to prepare him for higher responsibilities, because it is this performance and mastery of his present duties that qualities him for his higher assignment. Therefore, improving a worker's performance on his present job will enhance greatly his chances of being evaluated to higher position. 


\section{International Journal of Business Management and Economic Review}

Vol. 2, No. 04; 2019

ISSN: 2581-4664

IV. To Boost the Worker's Morale: By increasing the skills of the worker, he develops a more sense of self worth, confidence and trust in his own abilities. This acts as a morale booster and motivates him to higher performance.

V. It helps in teaching new employees the skills needed to perform in their new job

VI. It helps in the maintenance of suitable and necessary skills in the entire workforce

VII. It leads to improved service to the clientele

VIII. It increases employee motivation

IX. Staff training helps in increasing the productivity of workers, thereby leading to overall improved organizational productivity.

\section{EMPLOYEE'S PERFORMANCE}

Performance can be defined as the achievement of specified task measured against predetermined or identified standards of accuracy, completeness, cost and speed. In an employment contract, performance is deemed to be the accomplishment of a commitment in such a manner that releases the performer from all liabilities laid down under the contract. Efficiency and effectiveness are ingredients of performance apart from competitiveness and productivity and training is a way of increasing individual's performance (Cooke, 2000).

Kenney, (1992) stated that employee's performance is measured against the performance standards set by the organization. Good performance means how well employees performed on the assigned tasks. In every organization there are some expectations from the employees with respect to their performance. And when they perform up to the set standards and meet organizational expectations they are believed good performers. Functioning and presentation of employees is also termed as employee performance. This means that effective administration and presentation of employees" tasks which reflect the quality desired by the organization can also be termed as performance. While much is known about the economics of training in the developed world, studies of issues associated with training in less-developed countries are rarely found. Job characteristics and firm background were found to play key roles in determining training provision.

Salary has been viewed as an important determinant factor for employee increased performance and have been shown to influence an employee's decision to leave or to stay in the organization. Performance based payments have an effective relationship with performance improvements. Every worker wants to earn more so they put extra effort to produce more units. Performance based payments stimulate and motivate workers to be more creative in generating more efforts.

Due to performance based payments, capable workers earn more than ordinary workers. In case studies of different firms it was found that production increased, when system changed from monthly salary to daily wages. This means that increased wages have direct effect on employee performance. In case of fruit pickers, the progress of workers increased significantly when pay system was shifted from incentive pay. Managerial performance bonuses have the capability to enhance employee output. As far as posts of higher management are concerned, managers often emphasize on recruiting and retaining capable workers by moving from piece rate to salary. The core purpose of this activity is retaining efficient man power by providing more incentives (Evans \& Lindsay, 1999). 


\section{International Journal of Business Management and Economic Review}

Vol. 2, No. 04; 2019

ISSN: 2581-4664

\section{TRAINING AND EMPLOYEES PERFORMANCE IN ORGANIZTION: THE NEXUS}

Saleem and Mehwish (2011) suggest that training is major activity of Human Resources Development for employees' development. In this competitive world, training is the key strategy to achieve the organizational objectives. Training benefits employees' performance and organizational effectiveness. Attractive employee's performance is highly demanding in this competitive world for achieving the organizational performance. Niazi (2011) said in his study that training is beneficial for both employee and organization. Trained employee can face the current and future challenges of organization and achieve the competitive advantages. ALDamoe et al. (2012) said in his study that highly skillful and knowledgeable staff is very necessary for the improvement of the organization. Training increases the productivity of employee, improves the services of the employee and brings the positive change in the organization. Training gives the outcome in the shape of tangible and intangible.

According to Barzegar and Shahroz (2011), the most important impact of training on employees and organization performance is improve the quality and quantity of organization's output, increase in the organization's profitability, safeguarding the organization stability, minimizing the risk, decrease the organization cost and expenses, improving the management of the organization and establishing the organization as national and international entities. Training must be related to the mission and performance goals of organization. Singh and Madhumita (2012) believe that training is important mean to improve the employees' productivity which ultimately affects the organization performance and effectiveness. Okanya (2008) says that training directly influences on the HR outcomes (employee performance) and puts indirect effect on the organization performance that is mediated with employee performance. Muzffer et al, (2012) said trained employee is an important asset for the organization. Trained employee achieved the long term goals which are valuable for the organization success. Training improves the interpersonal skills of employee. Training maintains the capability of both employees and organization.

Most of the previous studies provide the evidence that there is a strong positive relationship between human resource management practices and organizational performance. Guest (1997) sees training and development programmes in his study as one of the vital human resource management practice, positively affects the quality of the workers knowledge, skills and capability and thus results in higher employee performance on job. This relation ultimately contributes to supreme organizational performance. The results of Farooq. \& Aslam (2011) study depicts the positive correlation between training and employee performance. Thus, we can predict from this finding that it is not possible for the firm to gain higher returns without best utilization of its human resource, and it can only happen when firm is able to meet its employee's job related needs in timely fashion. Training is the only ways of identifying the deprived need of employees and then building their required competence level so that they may perform well to achieve organizational goals.

According to Swart et al., (2005), bridging the performance gap refers to implementing a relevant training intervention for the sake of developing particular skills and abilities of the workers and enhancing employee performance. He further elaborate the concept by stating that training facilitate organization to recognize that its workers are not performing well and a thus their knowledge, skills and attitudes needs to be moulded according to the firm needs. There might be various reasons for poor performance of the employees such as workers may not feel 


\section{International Journal of Business Management and Economic Review}

Vol. 2, No. 04; 2019

ISSN: 2581-4664

motivated anymore to use their competencies, or may be not confident enough on their capabilities, or they may be facing work- life conflict. All the above aspects must be considered by the firm while selecting most appropriate training intervention that helps organization to solve all problems and enhance employee motivational level to participate and meet firm expectations by showing desired performance. As mentioned by Swart et al.(2005) this employee superior performance occur only because of good quality training program that leads to employee motivation and their needs fulfillment.

According to Wright and Geroy (2001), employee competencies changes through effective training programs; it does not only improves the overall performance of the employees to effectively perform the current job but also enhance the knowledge, skills and attitude of the workers necessary for the future job, thus contributing to superior organizational performance. Through training the employee competencies are developed and enable them to implement the job related work efficiently, and achieve firm objectives in a competitive manner. However, employee performance is also affected by some environmental factors such as corporate culture, organizational structure, job design, performance appraisal systems, power and politics prevailing in the firm and the group dynamics. If the above mentioned problems exist in the firm, employee performance decreases not due to lack of relevant knowledge, skills and attitude, but because of above mentioned hurdles. To make training effective and to ensure positive effect of training on employee performance these elements should be taken into consideration Wright and Geroy (2001).

Bartel (1994), reports that there is a positive correlation between effective training program and employee productivity, however to make it possible, (Swart et al., 2005), it is the responsibility of the managers to identify the factors that hinders training program effectiveness and should take necessary measures to neutralize their effect on employee performance. In addition, it is concluded that high level of employee commitment is achieved if training achieve learning outcomes and improves the performance, both on individual and organizational level.

Generally, it can be debated that the effect of training program on employee outcomes such as motivation, job satisfaction and organizational commitment, did not received much attention so far. Rare work was done to test whether firms can affect their workers attitude, through proper training interventions. According to Lang (1992) training should be planned in such a way that it results in organizational commitment. On the other hand Gaertner and Nollen (1989) proposed that employees' commitment is a result of some human resource practices, that is, succession planning and promotions, career development and training opportunities. All these practices, when achieved results in greater employee performance. Moreover, Meyer and Smith (2000), investigate the link between Human Resource Management practices and organizational commitment, so as to discover the causes of effective employee performance.

Although the above literature provides the evidences regarding the benefits of training and its positive influence on employee performance, Robbin (1987) argued that, management, mostly feel hesitant while investing in its human resource due to various reasons. Sometime, in spite of receiving effective and timely training programs, employee are intended to cash in for the sake of their own market value and employment opportunity, or willing to change job just because of higher salaries, and thus, firm investment in training results as a cost rather than profit. It is also observed that due to the resistance of the organization towards offering training, propels individuals to invest themselves for their career development and greater performance. 


\section{International Journal of Business Management and Economic Review}

Vol. 2, No. 04; 2019

ISSN: 2581-4664

To him, training sessions accelerate the initiative ability and creativity of the workforce and facilitate to avoid human resource obsolescence that may occur because of demographic factors such as age, attitude or the inability to cope with the technological changes. Obisi (2001) reported that training is a systematic process of enhancing the knowledge, skills and attitude, hence leads to satisfactory performance by the employees at job.

Moreover, training supports to shape employees' job related behavior and facilitate them to participate for the success of the organization and ultimately firm gets higher return due to superior performance of its employees. Further mentioned that a well trained worker is able to make a best use of organizational resources along with minimum level of wastages. When employees are well trained organization can delegate responsibility and authority to them with full confidence of ensuring organizational success.

\section{STAFF TRAINING / DEVELOPMENT AND ORGANIZATION PRODUCTIVITY. THE NEXUS}

According to Nel et al. (2004). Employee's development is, in addition to training as reviewed above, the major factor in the creation of employee human capital, which determines the long-term productivity of an employee's behaviour. While training is concerned with the employee's current job, development prepares the employee for future job requirements. Effective development programmes allow management to maintain a workforce that can adequately replace employees who may leave the company or who are moved to other areas. It also allows for employees to cope with newly developed technology, and ensures that adequate human resources are available for expansion into new areas.

He outlines the following effects of training and development on organizational productivity:

I. Increased success of quality projects

II. Reduction of project failures and defects

III. Reduction of staff turnover

IV. Minimal supervision needs

V. The ability to progress

VI. Greater capabilities to carry out more projects

VII. Changes in employee behaviour

\section{METHODS AND TECHNIQUES OF TRAINING STAFF IN ORGANIZATION}

\section{On-the-job Training}

On-the-job training as an employee's normal situation being designed to impart knowledge directly related to job performance. Campbell (1990) describes on the job training as a training given in workplace, where the trainer plays the role of supervisor. He also emphasizes that on-the-job training supplements all other forms of training, with the advantage of being provided to more people than is possible in other forms of training. He pointed out that on-thejob training is a critical and challenging task that has come to be identified with the future goals 


\section{International Journal of Business Management and Economic Review}

Vol. 2, No. 04; 2019

ISSN: 2581-4664

of many organizations. He further observes that organizations want employees who perform to expectations, achieving the goals and objectives of the organizations.

Burdwell and Holden (1976) see on-the-job training as a process which the supervisor or coworker teaches the individual to do the job. Also, On-the-job training approach requires competent higher level managers who can teach and coach trainees as they contribute to the aim of the enterprise. Gary (1991) posited that on-the-job training involves having a person learn a job by actually performing it on the job. He also posited that on-the-job training is the only type of training available to employees and usually involves assigning new employees to experienced worker or supervisor who then does the actual training. On-the-job training is a training normally given by a senior employee or manger. According to him, employee is shown how to perform the job and allowed to do it under the trainer's supervision. He posited that the advantage of on-thejob training is that no special facilities are required and the employee does productive work during the learning process. Job training method includes:

i. Orientation training

ii. Job-instruction training

iii. Apprentice training

iv. Internship and assistantship

v. Job rotation

vi. Coaching

\section{In-Service Training}

In-service training is the process of staff development for the purpose of improving the performance of an incumbent holding with assigned job responsibilities. He stresses that inservice training program is designed to strengthen the competences of extension of worker while on the job. For Udo Aka (1988) in-service training is the development of specific skill and attitude needed in the job maximize the productivity of the individual and improved the overall organizational efficiency.

Also, in-service training is a post entry training which employees undertake from time to time and from which they acquire knowledge designed to keep them abreast of development in their fields of activity. In-service training is always a process. It helps to equip employees for higher responsibilities or to diversify their skills. It is, like so many of the other personnel duties of the organization, a never-ending proceeding. According to Armstrong (1993) in-service training is the modification of behaviours through experience, the transfer of skills and knowledge from who have them to those who do not have to bring about a significant improvement in performance as a result of instruction, practice and experience. For Stoner (1982), in-service training is the teaching of technical statistics to non-managerial personal. Holt (1993) opines that in-service training allows employees to develop and enhance the skill, which socialization in different forms.

\section{Off-the-Job Training}

Robbin (1987) posited that there is number off-the-job training methods that managers may want to make available to employees. They highlight different forms of off-the-job training methods which are: lecturers, classroom lecturers, videos and simulation or trade school faculty of in-house personnel. Also, off-the-job training covers a number of techniques which include 


\section{International Journal of Business Management and Economic Review}

Vol. 2, No. 04; 2019

ISSN: 2581-4664

classroom lecturers, films, demonstrations, case studies, simulation exercise and programme instructions.

\section{Orientation or Induction Training}

Orientation is seen as the process of introducing new employees to the organization so that they can quickly become effective contributors. Robbin (1987), posited that induction courses or training are organized as a way of giving newly recruited staff a broad overview of the entire organization and enabling employees to see where they belong. He further opined that excessive induction training often covers the following objectives:

i. Introduction to the organization, its objectives and policies

ii. Explanation of the personnel policy of the firm

iii. Introduction to the department

iv. A brief history and structure of the organization

v. Introduction of the principal officers

Orientation is also seen as the introduction of new employees to the organization, work, unit and job. According to them, employees receive orientation from their fellow workers and from the company. Robbin (1987) observed that when people start to work in an organization for the first time, they are eager to know what sort of outfit they are getting into, what they supposed to do and whom they will work with. According to him, the most favourable time for gaining employee's attention and for moulding good habits among them is when they are new to the job.

\section{Vestibule Training}

According to Robbin (1987), Vestibule type of training refers to the practices of giving skills training to individuals after they are hired, but before they are assigned to specific job. This type of training is not widely used because it often focuses on skills that firms expect workers to have when they hired. He refers to vestibule training as training within a room. He posited that one of the advantages of vestibule training is that employees learn their jobs on the equipment they will be using. Gary (1991) refers to technique in which trainees learn on the actual equipment they will use on-the-job but are actually trained off the job. According to him, vestibule training therefore aims at obtaining the advantages of on-the-training without actually putting the trainees on the job.

\section{Apprenticeship Training}

Apprenticeship training is regarded as a system in which an employee is given instruction and experience, both-on-the-job and off-the-job in all practical and theoretical aspect of the work required in a skilled occupation, craft and trade. Apprenticeship training method is one of the oldest methods of training young people for a vocational trade.

\section{FACTORS THAT HINDERED TRAINING AND DEVELOPMENT OF EMPLOYEES IN ORGANIZATION}

Robbins et al. (2003) points out that many employers are opposed to training and development initiatives because they assume that the responsibility for training people to be workers falls on the school system, not on firms. In addition, they consider that it is the 


\section{International Journal of Business Management and Economic Review}

Vol. 2, No. 04; 2019

ISSN: 2581-4664

responsibility of the employees to learn how to do their job so that they are hired. Furthermore, they regard training and development programmes as an expense which it is difficult to convince shareholders to approve. According to the perspective of the researcher, if aligned with the goals, mission and objective of the organization, and supported by both the employer and the employee, training, development and education programmes delivered the right way and at the right time provide substantial returns for the employer in terms of increased productivity, knowledge, loyalty and profit (Robbins et al., 2003). In spite of the innumerable reasons and benefits derived from training, in most cases training and development programmes fail. This is regardless of whether the courses were attended in the best universities or delivered by the most prominent trainers.

Perry (2007) asserts that work appears among the first illustrations outlining the clear reasons why training and development programmes fail. His study was seconded by Kleiman (2003), who addressed the failures of training and development programmes in greater depth. In these two works, the first reason identified for the failure of training and development programmes stems from the training objectives not being aligned with the business needs. If the root of the problem of poor performance, for instance, it is related to factors such as reward systems, job design and motivation, which are not related to training, training will be pointless. Thirdly, in the absence of objectives to provide direction and focus, training will certainly not succeed. Training and development should include a focused process that allows the employee to ponder desired results. Objectives afford important direction and focus for learning the final product, which is a change in job performance.

Researchers also hold that when training is too expensive if compared to its short-term return on investment, then companies may consider it a failure and, therefore, unacceptable. However, the long-term pay-off may be rewarding. Training will be worthless if the participants regard the training programme as a mere event without any change to their behaviour. Whenever training is considered as a single event, the chances of behaviour change are slim. Training is also likely to fail if participants are not held accountable for the results. Generally, employees are not held accountable for the use of the contents of their course in the workplace. Unless they are held accountable, no change will occur in their behaviour (Kleiman, 2003).

If the conditions are not conducive to learning, the training efforts will have been in vain. Moreover, without the support of line management training will also fail. When there is no support from direct managers/supervisors, the employees will resist implementing the new skills and knowledge acquired during the training course. Management involvement is crucial to the learning process. Another reason for the failure of training and development occurs when the company fails to isolate the effects of training and development. However, other factors rather than training may influence performance. Thus, the advances directly related to training must be isolated. If not, some training programmes clearly noticeable as impacting on the bottom line may be discarded as irrelevant. For the success of a training programme, top executives' commitment is critical. Top management will not only allocate resources but, for the training and development to succeed, will also participate in the design of the process.

Lastly, training and development will be unsuccessful if there is a failure to provide feedback and use information about results. If the company fails to evaluate training by providing feedback, employees will not be able to know about their progress, nor facilitators to understand the success of their programmes. 


\section{International Journal of Business Management and Economic Review}

Vol. 2, No. 04; 2019

ISSN: 2581-4664

At Akwa Ibom Ministry of Finance, employees are provided with training; however, after training they fail to transfer whatever they have learnt to their working environment in order to improve performance. When an employee retires or leaves the organization it becomes difficult to find someone internally to fill the vacant post, even though other employees have been sent for training for such positions. It has been found that adults prefer different training methods to younger employees; older adults prefer practical training methods to classroom training (theoretical training).

According to Anderson (2003), the following are the factors affecting employee performance to increase productivity:

\section{Experience}

Hiring employees who do not have the proper background for the job is one of the things that start a performance downward spiral (Anderson, 2003). Company training should be used to enhance the employee's background. If an employee has undergone extensive training but is still experiencing performance issues, then the problem could be that the employee does not possess the necessary experience to do the job.

\section{Work-home Balance}

As much as an employer may not want to be affected by the personal life of his employees, personal problems can sometimes affect employee performance. Managers need to be sensitive to employees personal problems, and be prepared to discuss the issues with employees when necessary. If an employee requires time off to deal with a personal problem, then granting that time off will help to show all employees that the company values them (Anderson, 2003).

\section{Manager Interaction:}

If an employee does not get feedback from his/her manager, then he/she has no idea on how to rate his/her performance. Managers should be trained to give positive and negative employee feedback. In negative situations, the manager should work with the employee to create a programme that will help address the performance shortcomings. It is easier for employees to improve their performance when they know what they are doing right and what they are doing wrong (Anderson, 2003).

\section{Setting Goals:}

To help employees improve their performance, employers need to set goals that employees are required to achieve, performing to the minimum standards means the employee is doing his job, and that can help an employee understand what is expected of him at a minimum. It would also be helpful to create incentives that will give employees motivation to go beyond the set goals (Anderson, 2003). 


\section{International Journal of Business Management and Economic Review}

Vol. 2, No. 04; 2019

ISSN: 2581-4664

\section{THEORETICAL FRAMEWORK}

Based on the nature of the subject matter, which has to do with Staff Training and Employees Performance in an Akwa Ibom State Ministry of Finance as a case study, Abraham's Maslow Theory of Need is adopted as theoretical foundation for the study. The "motivation to work" published by Maslow probably provided the field of organizational behaviour and management with a new way of looking at employees job attitudes or behaviours in understanding how humans are motivated. Probably the best-known conceptualization of human needs in organizations has been proposed by this theory. Abraham Maslow was a clinical psychologist who introduced his theory based on personal judgment, which was generally known as the Need Hierarchy Theory. According to him if people grew in an environment in which their needs are not met, they will be unlikely to function as healthy individuals or well-adjusted individuals. This idea was later applied to organisations to emphasize the idea that unless employees get their needs met on the job, they will not function as effectively as possible.

Specifically Maslow theorized that people have five types of needs and that these are activated in a hierarchical manner. This means that these needs are aroused in a specific order from lowest to highest, such that the lowest-order need must be fulfilled before the next order need is triggered and the process continues. If you look at this in a motivational point of view Maslow's theory says that a need can never be fully met, but a need that is almost fulfilled does not longer motivate. According to Maslow you need to know where a person is on the hierarchical pyramid in order to motivate him/her. Then you need to focus on meeting that person's needs at that level (Robbins 2001) According to Greenberg and Baron (2003) the five needs identified by Maslow corresponds with the three needs of Alderfers ERG theory. Whereas Maslow theory specifies that the needs be activated in order from lowest to highest Alder's theory specifies that the needs can be activated in any order. His approach is much simpler than Maslow's. Alder specifies that there exist three main needs as opposed to five postulated by Maslow. This human basic needs include existence, relatedness and growth. These needs according to Alder need not necessarily activated in any specific order and may be activated at any time.

According to him Existence needs corresponds to Maslows physiological needs and safety needs. Relatedness needs corresponds to Maslow social needs and growth needs corresponds to esteem and self-actualization needs by Maslow.

I. Physiological needs are the need at the bottom of the triangle and include the lowest order need and most basic. This includes the need to satisfy the fundamental biological drives such as food, air, water and shelter. According to Maslow organisations must provide employees with a salary that enable them to afford adequate living conditions. The rationale here is that any hungry employee will hardly be able to make much of any contribution to his organisation.

II. Safety needs: Safety needs are activated after physiological needs are met. They refer to the need for a secure working environment free from any threats or harms. Organisations can provide these need by providing employees with safety working equipment e.g. hardhats, health insurance plans, fire protection etc. The rationale is that employees working in an environment free of harm do their jobs without fear of harm. Once 


\section{International Journal of Business Management and Economic Review}

Vol. 2, No. 04; 2019

ISSN: 2581-4664

physiological needs are met, one's attention turns to safety and security in order to be free from the threat of physical and emotional harm. Such needs maybe fulfilled by: living in a safe area, medical insurance, job security, and financial reserves.

III. Social needs: This represents the third level of needs. They are activated after safety needs are met. Social needs refer to the need to be affiliated that is (the needed to be loved and accepted by other people). To meet these needs organisations encourage employee's participation in social events such as picnics, organisations bowling etc. Once lower level needs are met, higher level motivators awaken. Social needs are those related to interaction with others and may include: friendship, belonging to a group, and giving and receiving love.

IV. Esteem needs: It includes the need for self-respect and approval of others. Organisations introduce awards banquets to recognize distinguished achievements. After a person feels that he or she belongs, the urge to attain a degree of importance emerges. Esteem needs can be categorized as both external and internal motivators. Internally motivating esteem needs are those such as self-esteem, accomplishment, and self-respect. External esteem needs are those such as reputation, social status, and recognition.

V. Self-actualization: Is the summit of Maslow's motivation theory. It is about the quest for reaching one's full potential as a person. They are said to have frequent occurrences of peak experiences, which are energized moments of profound happiness and harmony. According to Maslow, only a small percentage of the population reaches the level of selfactualization This refers to the need to become all that one is capable of being to develop ones fullest potential. The rationale here holds to the point that self-actualised employees represent valuable assets to the organisation human resource.

Most research on the application of need theory found that although lower-level managers are able to satisfy only their deficiency needs on the jobs, managers at the top level of organisations are able to satisfy both their deficiency and growth needs (Greenberg \&Baron 2003). This view was supported by Shipley \& Kiely (1988), who argue that as " need satisfaction is an attitude, and that it is perfectly possible for a worker to be satisfied with his/her need, but not be motivated the reverse of which holds equally true. Hence, need satisfaction and motivation are not synonymous and both need fulfillment and un- fulfillment can have negative as well as positive influence on motivation

The greatest value of Maslows need theory lies in the practical implications it has for every management of organisations (Greenberg \& Baron 2003). The rationale behind the theory lies on the fact that it's able to suggest to managers how they can make their employees or subordinates become self-actualized. This is because self-actualized employees are likely to work at their maximum creative potentials.

Based on the above theory, the management of Akwa Ibom Ministry of Finance will attain or get what they demand or want from its employees if only they are all well motivated in terms of training because a well trained employee is a plus to the organization. Training is one the needs of every employees theorized by Abraham Maslow. A general review of the literature on motivation and training reveals that employees do not agree on a generally acceptable classification of human needs. There is general agreement, however, on the existence of classes of needs. The physiological, biological or basic needs which require satisfaction for survival and 


\section{International Journal of Business Management and Economic Review}

Vol. 2, No. 04; 2019

ISSN: 2581-4664

the psychogenic, social or secondary needs which appear after the biological needs have been reasonably satisfied.

In Nigeria, as well as other pre-industrial countries where the level of education is low and where skilled manpower is in short supply, the highest level of aspiration of many workers remains within the range of satisfying the lower-level needs, according to Maslow's classification. However, to people who have no chance of moving up their occupational or professional ladder, the complete satisfaction of their basic biological needs may represent a level of self actualization. This is not a contradiction of Maslow because he maintained that when one level of need is reasonably satisfied, another need will arise to take its place. There is no end to this until all human needs are satisfied.

The issue raised by Hertzberg as to whether training and money can be continually used as a motivator is relevant here. Hertzberg has postulated that if people are trained and paid a wage they perceive as fair, paying them more would not increase their productivity or morale. Unfortunately, the acquisition of wealth is a form of self-actualization for most Nigerian workers and many others all over the world. For those people, training can be said to satisfy the basic physiological and security needs because a trained employees will positively increase the working standard and ethics of the organization. It can also help to satisfy some of the egoistic needs as it has become a status symbol indicating a culmination of other successes in life.

\section{CONCLUSION}

Companies whose investment perspective is on human resource management view training as an opportunity to increase long-term productivity. Investing in training and development is imperative for any organisation, which will certainly realize a return on its investment in training and developing its workers. Workers are essentially assets to an organisation and should therefore be treated as human capital. The more that is invested in them, the more that can be expected from them in terms of performance behaviour which can give the organization its competitive edge. The evaluation process that follows training is very important as there may be deficiencies in the training programme; therefore feedback is essential if management is to address issues that may have to be revised and/or enhanced. Effective employee training leads to an increase in quality as a result of potentially fewer mistakes. Moreover, effective development programmes allow for the organisation to maintain a workforce that can adequately replace employees who may leave the company or who are moved to other areas. On the individual level, the employee must carry out self-assessment, where he/she is expected to identify his/her opportunities and needs for improvement.

\section{RECOMMENDATIONS}

In the light of the findings and conclusion of the study, the following recommendations are made, which if adopted would make the training function of the Akwa Ibom Ministry of Finance more productive and efficient.

- Seminars and workshops should be organized for the staff of Akwa Ibom Ministry of Finance on the importance of systematic approach of training and proper procedure to follow in identifying skill gaps in the various departments. 
Vol. 2, No. 04; 2019

ISSN: 2581-4664

- The Ministry should be sensitized on the importance of sending the right employee on training. They should not see training opportunities as pay back opportunities for their loyalists.

- Recommending employees for training based on favoritism should be discouraged by the management.

- A mechanism should be created for proper assessment and evaluation of employee performance after training. Some of the employee performance indicators enumerated in this research work could be adopted by the organizations.

- Working conditions in the organization should be improved so that they become conducive to the transfer of learning.

- The employer should have compulsory training programmes for all employees in order to improve the knowledge and understanding of annual business strategy and objectives.

\section{REFERENCES}

Anderson, A. (2003). Industrial Psychology (3rd Ed); New Jersey: Pearson Prentice Hall.

Armstrong, M. (1993), A Handbook on Personnel Management Practice, (5th edition), London: Kogan Page.

Bartel, A. (1995), Training, Wage Growth, and Job Performance: Evidence from a company database. Journal of Labor Economics 13, 401-425.

Barzegar, N. \& Shahroz, F. (2011) A Study on the Impact of on the job training Courses on the Staff Performance (A Case Study).Social and Behavioral Sciences., 29 (2011) : 1942 1949

Beardwell, I. Holden, L. \& Claydon, T. (1992), Human Resource Management a Contemporary Approach: 4th Ed. Harlow. Prentice Hall

Becker, B. and Gerhart, B. (1996), "The Impact of Human Resource Management on Organizational Performance: Progress and Prospects", Academy of Management Journal, 39(4), 779-801.

Berge Z. L. (ed) (2001), Sustaining Distance Training: Integrating Learning Technologies into the Fabric of the Enterprise, San Francisco: Jossey-Bass.

Brown, P., (1996), "A Meta-Analysis and Review of Organizational Research on Job Involvement" "e Psychological Bulletin, Vol; 120, Pp. 235-255.

Cambell, J. (1990). Personnel Training and Development: Annual Review of Psychology.

Chris Amisano, (2010), eHow contributor "Relationship between training and employee performance".

Cole, S. (2002), Personnel and Human Resources Management: 5th Edition. London: Continuum Books.

Evans, P. and Lindsay (1999) The Global Challenge: Framework for International Human Resource Management. Boston: McGraw-Hill.

Ezeani, E. and Oladele, I. (2013), Fundamentals of Public Administration: Enugu: Zik-Chuks Publishers. 


\section{International Journal of Business Management and Economic Review}

Vol. 2, No. 04; 2019

ISSN: 2581-4664

Fakhar U. Afaq, Anwar Khan (2008), "Case of Pearl Continental Hotels in Pakistan, Relationship of training with Employees' Performance in Hoteling Industry".

Farooq, M. \& Khan, M. A. (2011), Impact of Training and Feedback on Employee Performance: Far East Journal of Psychology and Business, 5(1): 23-33.

Flippo, E. (1976), Personnel Management (6th Ed), New York: McGraw-Hill.

Gaertner, E. and Nollon, O. (1989), Training Skills: How to Improve the Skills and Performance of your Employees. Ventures: Eric Garner \& Ventures Publishing ApS. Available at: http://www.bookboon.com /

Gordon, B. (1992). Are Canadian Firms under Investing in Training? Canadian Business Economics 25-33.

Guest, D. E. (1997), Human Resource Management and Industrial Relations: Journal of Management Studies 245, 503-521.

Harel, J. (1999). Operations management (8thEd) New Jersey: Pearson Education.

Harrison, R. 2000. Employee Development: Silver Lakes, Pretoria. Beekman Publishing.

Hills, P. (2000) "Personality and Individual Differences" Journal of Psychology and Religion Vol 10 No 6 pp 129-134

Iftikhar A. and Siraj Din, (2009) Gomal Medical College and Gomal University, D.I.Khan,Pakistan, "Evaluating Training and Development"

Johnson, R. and Redmond, D. (2006), The Art of Empowerment: The Profit and Pain of Employee Involvement. London: Financial Times Management.

Kennedy, J. (1992). The Impact of Training and Development on Job Performance: A Case Study of the Judicial Service of Ghana. A thesis submitted to the Institute of Distance Learning, Kwame Nkrumah University of Science, and Technology, (2009): 1-77

Kleiman, L. (2003). Human Resource Management: (3rdEd) USA: Atomic Dog.

Laurie, B. (1994). Training Investments as a Predictor of Banks' Subsequent Stock Market Performance (online): Available at http://www.mcbassi.com/resources/documents/McBassi BankingWhitePaper-

Luo, X (June, 2000). The Rise of Personal Development Training in Organizations: A Historical and Institutional Perspective on Workplace Training Programs in the U.S. Perspectives, Vol. 1, No. 6.

Meister, J. (1997), Corporate Universities: Lessons in Building a World-Class Work Force, NY: McGraw-Hill, Inc.

Miller, V. A. (1996). The History of Training: In Craig, R. L. (Ed.), The ADTS Training and Development Handbook: A Guide to Human Resource Development (4th ed, pp. 3- 17), New York: McGraw-Hill.

Meyer, R. and Smith, E. (2000), Cognition and Instruction: their Historic Meeting within Educational Psychology, Journal of Educational Psychology 84(4), 405-412. http://dx.doi.org/10.1037\%2F0022-0663.84.4.405. [accessed 2 May 2012].

Mullins, L. (1999) Management and Organizational Behaviour: 5th ed. New Jesey: FT Prentice Hall

Muzaffar, M. U.,Salamat, S. H. \& Ali, M. M. (2012). Impact of Trainings on Employees Outcome in IT Sector Pakistan. Global Journal of Management and Business Research., 12(6): 20-26. 


\section{International Journal of Business Management and Economic Review}

Vol. 2, No. 04; 2019

ISSN: 2581-4664

Nadler, L., \& Nadler, Z. (1984), Developing Human Resources: San Francisco: Jossey-Bass.

Nel, P., Gerber, P., van Dyk, P., Haasbroek, D., Schultz, H., Sono, T. and Werner, A. (2004). Human resources management (6thEd) South Africa: Oxford University Press.

Noe, E. et al. (2003). Human Resource Management: Gaining Competitive Advantage. $3^{\text {rd }}$ edition McGraw-Hill. Boston, USA.

Niazi, S. A. (2011). Training and Development Strategy and its Role in Organizational Performance: Journal of Public Administration and Governance. 1(2): 2161-7104

Obisi, C. (2001). Employee Training and Development in Nigerian Organisaitons: Some observations and agenda for research. Australian Journal of Business and Management Research, 1 (9), 82-91.

Okanya, P. (2008). Reconciling Organizational Performance and Employee Satisfaction through Training: the Case of Soroti District Local Government. (Unpublished) MA. Thesis, Graduate School of Development Studies: 66pp

Olalere, T. and Adesoji, A. (2013), Human Capital Development in First Bank of Nigeria Plc, Mediterranean Journal of Social Science 4(2). MCSER-CEMAS Sapienza University of Rome.

Robbins, P., Odendaal, A. and Roodt, G. (2003) Organizational behavior: Global and Southern African perspectives. South Africa: Pearson Education.

Robert O. Brinkerhoff, (2006). Increasing impact of training investments: an evaluation strategy for building organizational learning capability (online): Available at www.emeraldinsight.com Vol. 38 No. 6, pp. 302-307, Emerald Group Publishing Accessed 18/4/2011.

Saleem, Q., Shahid, M. \& Naseem, A. (2011) .Degree of influence of training and development on employee's behavior. International Journal of Computing and Business Research., 2(3): 2229 6166.Salas, E. and Cannon-Bowers, J. A. (2001), The Science of Training: A Decade of Progress, Annual Review of Psychology, 52, 471-499.

Stone, J. (2002), Human Resource Management 2nd Edition, John Wiley \& Sons 2002.

Sultana, A., Irum, S., Ahmed, K. \&Mehmood, N. (2012). Impact of Training on Employee Performance: A Study of Telecommunication Sector in Pakistan. Interdisciplinary Journal of Contemporary Research in Business, 4 (6), 646-661.

Swart, J., Mann, C., Brown, S. \& Price, A. (2005). Human Resource Development: Strategy and Tactics. Oxford. Elsevier Butterworth-Heinemann Publications.

Wright, P. \& Geroy, D. G. (2001). Changing the mindset: the training myth and the need for word-class performance. International Journal of Human Resource Management 12,4, 586-600. Ying, R. (2003). Case Study Research: Design and Methods. 3rd Ed. Applied Social Research Methods, Vol. 5. 